\title{
A comparative analysis on serum antibody levels of sheep immunized with crude and thiol-purified excretory/secretory antigen of Haemonchus contortus
}

\author{
S ArunKumar*, S Abdul Basith and S Gomathinayagam \\ Department of Veterinary Parasitology, \\ Madras Veterinary College, Tamilnadu veterinary and animal sciences university, Chennai, India. \\ * Corresponding author email: arunsgr@rediffmail.com \\ Received: 24-10-2011, Accepted: 11-11-2011, Published Online: 24-01-2012
}

doi: $10.5455 /$ vetworld.2012.279-284

\begin{abstract}
In vitro culture of live adult worms were made in RPMI 1640 medium at a concentration of approximately $50 \mathrm{worms} / \mathrm{ml}$ in a culture flask at $37^{\circ} \mathrm{C}$ for 24 hours and the culture supernatant was used as antigen. The E/S antigen was purified by thiol sepharose affinity chromatography. On western blot analysis, it was demonstrated that the crude E/S antigen showed five reactive bands at 24, 29, 46, 66 and $93 \mathrm{kDa}$ and the Thiol - purified antigen showed a single reactive band at $66 \mathrm{kDa}$. In immunization trial, sheep were immunized with $500 \mu \mathrm{g}$ of crude and thiol - purified E/S antigen along with montanide as adjuvant on day 0,30 and 60 intramuscularly. Further, the assessment of serum antibody levels in immunized sheep was made at weekly intervals by enzyme linked immuno sorbent assay (ELISA). It was observed that the mean absorbance values were significantly $(\mathrm{P} \leq 0.01)$ higher up to 20 weeks post immunization in Group-I (purified antigen) than Group-II (crude antigen) compared to unimmunized control group.

Key words : Haemonchus contortus, Excretory / Secretory antigen, Thiol - sepharose, antibody, ELISA.
\end{abstract}

To cite this article: ArunKumar S, AbdulBasith S and Gomathinayagam S (2012) A comparative analysis on serum antibody levels of sheep immunized with crude and thiol-purified excretory/secretory antigen of Haemonchus contortus, Vet. World. 5(5):279-284, doi: 10.5455/vetworld.2012.279-284

\section{Introduction}

Haemonchus contortus is a blood-sucking nematode primarily occurring in the abomasum of sheep and goats. It has been ranked as the most important parasite of small ruminants in all tropical and temperate areas of the world (Sood, 1981; Meeusen, 1996; Newton and Munn, 1999). It causes great economic losses in sheep industry including decreased weight gain and milk yield (Gross et al. 1999). The only currently available means of control of this parasite is through periodic use of anthelmintic drugs and pasture management. But the efficacy of these strategies is under threat from the emergence of anthelmintic resistant strain of this parasite (Waller et $a l .$, 1996). Concern has also been raised regarding the presence of anthelmintic residues in the food chain and environment (Skuce et al., 1999). Therefore, control of $H$. contortus infection through vaccine would be an alternative strategy.

Analysis of host immune response to helminth parasites is hampered by two main factors;

(I) the complexity of antigen profile of parasites

(ii) the presence of cross-reactive determinants on antigens. To identify specific antigens, exeretory/ secretory $(\mathrm{E} / \mathrm{S})$ products of helminthes have received increasing attention. This is due to the fact that $(\mathrm{E} / \mathrm{S})$ products of helminthes usually display a relatively simple antigenic composition compared to the somatic worm antigens. The E/S products play numerous roles in the host-parasite relationship such as host tissue penetration, degradation of host proteins for nourishment, modulation of host immune response and the prevention of blood clotting etc (Karanu et al. 1993, Yatsuda et al. 2003 and Suchitra and Joshi 2005). In recent years, attempts have been made to characterize the excretory / secretory (E/S) products of $H$. contortus as these substances could be potential target for the immunological control of the disease. Hence, the present study was carried out to evaluate the efficacy of crude and purified excretory / secretory antigens of $H$. contortus in inducing protective immune responses in sheep.

\section{Materials and Methods}

Preparation and antigen: Adult Haemonchus contortus worms were collected from abomasum of 
sheep slaughtered at corporation slaughter house, Perambur,Chennai. The collected worms were washed five times in normal saline and subsequently washed five times in phosphate buffered saline (PBS, $\mathrm{pH} 7.4$ ), containing penicillin $(500 \mathrm{IU} / \mathrm{ml})$ and streptomycin $(5 \mathrm{mg} / \mathrm{ml})$. Then, the worms were identified based on morphological features using standard keys (Soulsby, 1982). After thorough washing, the worms were used for preparing the antigens.

The fresh and highly motile worms were transferred to RPMI 1640 medium containing penicillin (500 IU/ $\mathrm{ml})$ and streptomycin $(5 \mathrm{mg} / \mathrm{ml})$ and cultured at a concentration of approximately 50 worms per $\mathrm{ml}$ in a culture flask at 5 per cent $\mathrm{CO}_{2}$ atmosphere at $37^{\circ} \mathrm{C}$ for 24 hours. The medium was changed every 6 hours after incubation and fresh medium was added with 2 per cent glucose throughout incubation. Worm viability was monitored throughout this period on the basis of motility, integrity of the worms. Moreover, random samples of the culture fluid obtained during and directly after the incubation period were plated out on agar in order to exclude bacterial contaminations. After the incubation period, the culture medium was collected by decantation and filtered through a 0.22 ì $\mathrm{m}$ filter (Millipore). Then, the culture medium was centrifuged at $10,000 \mathrm{rpm}$ for 30 minutes at $4^{\circ} \mathrm{C}$ and the supernatant was labelled as excretory/ secretory (E/S) antigen. This culture procedure was repeated several times in order to obtain sufficient quantity of antigen. Finally, the antigen obtained was concentrated by dialysis (membrane cut off, $12 \mathrm{kDa}$ ) against polyethylene glycol (PEG 6000 - SRL, India) over a period of 6 hours. The concentrated material was added with $1 \mathrm{mM}$ phenyl methyl sulfonyl fluoride (PMSF) and $1 \mathrm{mM}$ ethylene diamine tetra acetic acid (EDTA) to prevent proteolysis and stored at $-20^{\circ} \mathrm{C}$ with 0.02 per cent sodium azide as preservative till further use. The protein concentration of the E/S antigen was determined using bicinchoninic acid (BCA) method (Smith et al. 1985) using protein estimation kit (Genei, Bangalore).

Purification of E/S antigen: Affinity chromatography was carried out as per method described by Knox et al., (1999). The thiol- sepharose packed column $(5 \mathrm{~cm}$ bed height) was equilibrated with equilibration buffer (pH 7.4) at a flow rate of $5 \mathrm{ml}$ per hour. Protein sample (10mg) was applied onto a column. The unbound fractions were eluted by washing the column with 10 bed volumes of equilibration buffer till the optical density (OD) value at $280 \mathrm{~nm}$ returned to a steady base line. Then, the thiol bound fractions were eluted in elution buffer (10mM Tris, $0.5 \mathrm{M} \mathrm{NaCl}, 50 \mathrm{mM}$ DTT) in $1 \mathrm{ml}$ fractions at a flow rate of $5 \mathrm{ml}$ per hour. Based on the OD value at $280 \mathrm{~nm}$, the peak fractions were pooled and concentrated by dialysis against PEG 6000 . The purified antigen was stored at $-20^{\circ} \mathrm{C}$ till further use. The Protein concentration of the purified E/S antigen was determined using BCA method (Genei, Bangalore).

Characterization of E/S antigen : Sodium dodecyl sulphate polyacrylamide gel electrophoresis (SDSPAGE) was carried out to observe the polypeptide patterns of thiol- purified E/S antigen of $H$. contortus under reducing gel conditions as per method of Laemmli(1970). The immunogenic fraction was identified by western blot analysis according to the method described by Towbin et al. (1979) using mini trans-blot electrophoretic transfer cell (Biorad, USA). After the electrophoretic run, the nitrocellulose membrane was removed and was blocked in blocking buffer at $37^{\circ} \mathrm{C}$ for 2 hours. Then the membrane was washed in washing buffer three times with gentle agitation for 5 minutes each. The membrane was incubated in sheep immune serum at a dilution of 1:100 in PBS for 2 hours at $37^{\circ} \mathrm{C}$ with gentle shaking. The nitrocellulose membrane was washed in washing buffer three times for 5 minutes each and immersed in solution of 1:1000 diluted anti-sheep IgG HRP conjugate (Sigma, USA) in PBS for 2 hours at $37^{\circ} \mathrm{C}$. Then the membrane was washed three times in washing buffer for 5 minutes each. The membrane was treated with substrate solution (DAB) till the bands appeared.

Immunization trial: Immunization trial was conducted in sheep to evaluate the efficacy of thiol-purified E/S antigen of $H$. contortus. Twelve Madras red breeds of male sheep aged around 8 months old were procured from Livestock Research Station, Kattupakkam, Tamilnadu. All the sheep were maintained in clean animal shed and were fed with concentrate mixture (200g per animal), green fodder and water ad libitum during the research period. All animals were dewormed with ivermectin at the dose rate of $0.2 \mathrm{mg} /$ $\mathrm{Kg}$ body weight 21 days prior to start of experiment. Sheep were divided into two groups, each group consists of 6 sheep. In group I, sheep were immunized with $500 \mu \mathrm{g}$ of affinity purified $\mathrm{E} / \mathrm{S}$ antigen along with adjuvant montanide ISA 206 on day 0,30 and 60 through intramuscular route. In group II, sheep were used as unimmunized control .

Standardization of ELISA: Serum antibody responses in sheep immunized with affinity purified E/S antigen was evaluated by enzyme linked immuno sorbent assay (ELISA). Monospecific positive serum was 
obtained from Division of Parasitology, IVRI, Izatnagar. Negative serum was collected from a healthy 2 to 3 weeks old Madras red breed of lamb from Livestock Research Station, Kattupakkam (TANUVAS) Tamilnadu. Test serum samples were collected at weekly intervals from all the sheep from 0 to 21 weeks of experimental period.

The optimum concentration of antigen, serum and conjugate (anti-sheep IgG/HRP, Sigma, USA) were determined by checker board titration method using serial dilution of antigen, serum and conjugate. Four different concentrations of antigen (namely $1 \mu \mathrm{g}$ / $\mathrm{ml}, 2 \mu \mathrm{g} / \mathrm{ml}, 5 \mu \mathrm{g} / \mathrm{ml}, 7 \mu \mathrm{g} / \mathrm{ml}$, diluted in carbonatebicarbonate buffer) were added to the 96 well flat bottom ELISA plate.

Serial dilutions of serum (known positive and negative) namely 1 in 100, 1 in 200, 1 in 400, 1 in 800, 1 in 1600 and 1 in 3200 were used. The conjugate was checked in dilutions of 1 in 1000, 1 in 2000, 1 in 5000 and 1 in 10000. The test was conducted and the OD (optical density) values were arrived for each concentration. The maximum difference in $\mathrm{OD}$ value obtained between positive and negative serum was selected as the optimum dilution for use. The optimum concentration of antigen $(2 \mu \mathrm{g} / \mathrm{ml})$, serum ( 1 in 200) and the conjugate ( 1 in 5000) was arrived by this method which was used in the test procedure. ELISA was carried out following the method of Knox et al. (2003).

Statistical analysis: The data obtained in the present study were statistically analyzed by ANOVA (Snedecor and Cochran 1968)

\section{Results}

In the present study, a total of 12,000 live adult Haemonchus contortus worms were collected from the abomasum of sheep. During the incubation period, adult worms remained viable as assessed qualitatively by both motility and clumping tendency. No bacterial contamination was detected during invitro culture. The protein concentration of E/S antigen was found to very from 1.2 to $1.5 \mathrm{mg} / \mathrm{ml}$ in different batches.

In the present study, the E/S antigen of $H$. contortus was purified by affinity chromatography using Thiol-sepharose column. The unbound fractions were collected by washing the column with equilibration buffer till the OD value returned to a steady base line and the fractions $(7,8,9,15,16$ and 17) were pooled. Then, the thiol-bound fractions were eluted using elution buffer and the peak fractions (47to53 ) were pooled and concentrated by dialysis against PEG 6000. The elution profile of E/S antigen showed two minor peaks in unbound fractions and one major peak in bound fractions. The protein content of purified E/S antigen was found to be $1.6 \mathrm{mg} / \mathrm{ml}$.

On characterization of crude E/S antigen by SDS- PAGE revealed five polypeptide bands at 24, 29, 46, 66 and $93 \mathrm{kDa}$ molecular weights. A single band at $66 \mathrm{kDa}$ was detected in affinity purified E/S antigen. On western blot analysis, the crude E/S antigen probed with serum from sheep infected with $H$. contortus showed five reactive bands at 24,29,46, 66 and 93 $\mathrm{kDa}$. Similarly, the affinity purified E/S antigen probed with serum from sheep infected with $H$. contortus showed a strong reactive band at $66 \mathrm{kDa}$.

Further, the assessment of serum antibody levels were monitored in immunized and control sheep at weekly intervals by ELISA. The mean absorbance values of ELISA from immunized and unimmunized control groups are presented in table-1. In Group-I, the mean absorbance values gradually increased from second weeks post immunization and reached a peak value of $1.26 \pm 0.05$ on eighth week post immunization. The serum antibody levels in affinity purified group were significantly $(\mathrm{P} \leq 0.01)$ higher and was maintained up to 20 weeks post immunization compared to unimmunized control group. In Group-II the mean absorbance values gradually increased from second weeks and reached a peak value of $0.70 \pm 0.02$ on ninth week post immunization. Whereas, the mean absorbance values was low $(0.09 \pm 0.01$ to $0.16 \pm 0.01)$ throughout the observation period. This study revealed that the mean absorbance values of Group-I were significantly $(\mathrm{P} \leq 0.01)$ higher than Group-II through out the observation period.

\section{Discussion}

In recent years, exeretory/ secretory $(\mathrm{E} / \mathrm{S})$ products of helminthes have received increasing attention. This is due to the fact that excretory / secretary products of helminthes usually display a relatively simple antigenic composition compared to the somatic worm antigens. Further, they play numerous roles in the host-parasite interactions. In the present study, invitro culture of live adult worms was made and the E/S antigen was isolated. Similar culture procedures were reported by several workers for isolating the E/S antigen from Haemonchus contortus (Karanu et al. 1993, Schallig and Leeuwen 1997, Joshi and Singh 1999, Rathore et al. 2006, Anbu and Joshi 2008).

The protein concentration obtained in this study is in accordance with the reports of Schallig et al (1994), Schallig and Leeuwen (1997), Bakker et al (2004) and Rathore et al (2006).

Protein fractionation by virtue of covalent thiol- 
Study of Serum level of sheep immunized with crude and thiol-purified excretory/secretory antigen of $H$. contortus

Table - 1. Mean (+ S.E.) absorbance values of ELISA in immunized and control sheep

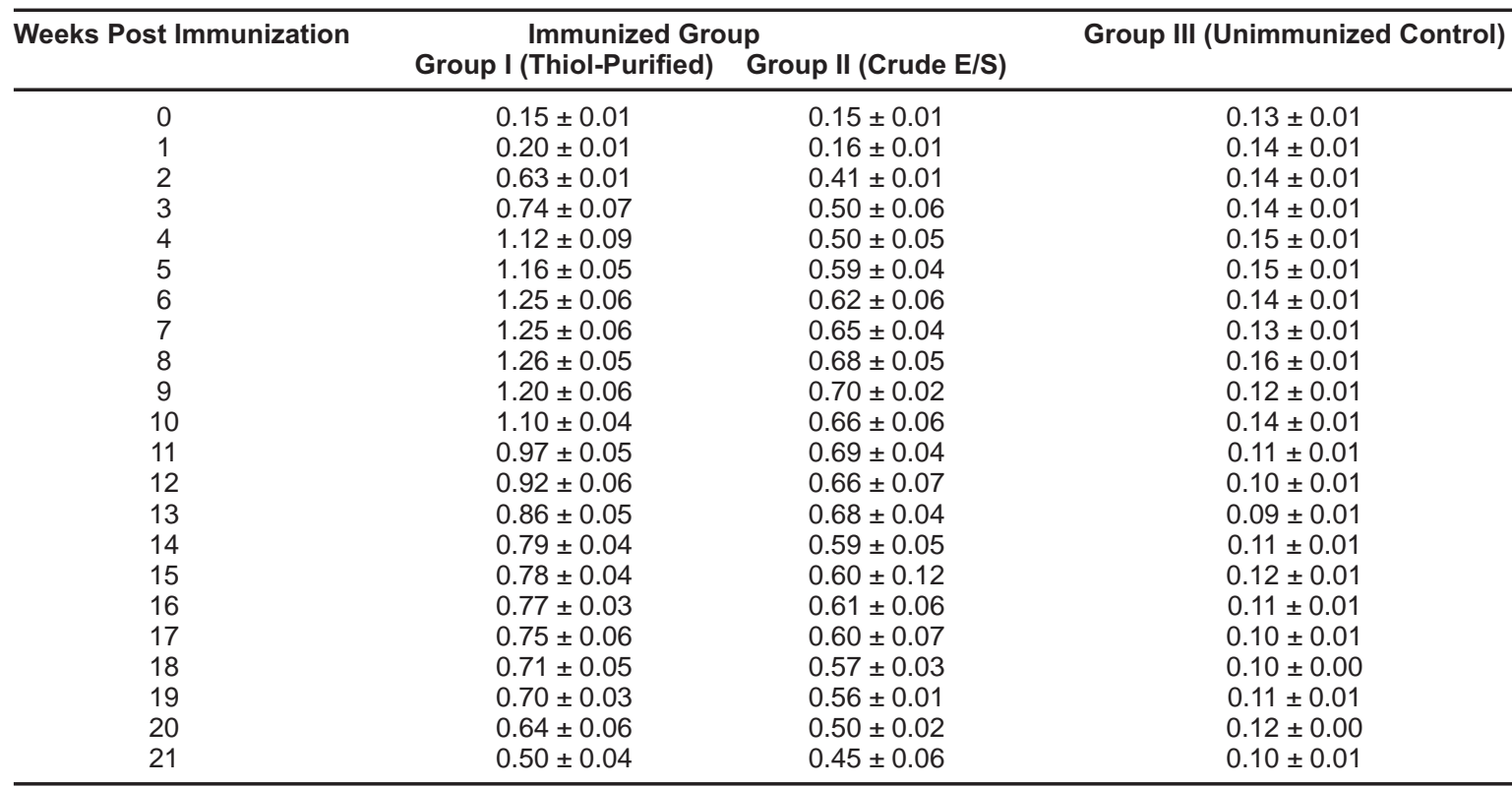

Table - 1a. Analysis of variance

\begin{tabular}{lll}
\hline Source & D.F. & F \\
\hline Groups & 2 & $1682.322^{* *}$ \\
Periods & 21 & $14.7296^{* *}$ \\
\hline
\end{tabular}

** Highly significant $(\mathrm{P} \leq 0.01)$

binding properties is a highly specific method resulting in the complete removal of many individual proteins. Thiol binding protein fractions of $\mathrm{E} / \mathrm{S}$ and membrane proteins of parasitic nematodes have been shown to contain protective properties.

Theoretically all proteins containing reduced cysteine residues can bind covalently to Thiol-sepharose. The reactivity and accessibility of the $\mathrm{SH}$-groups is determined by their sequence context and location within the tertiary structure, which also determines the ease by which bound proteins can be eluted. In addition, proteins may stick non-covalently with high affinity to bound proteins although the binding and the washing were done in a high-ionic strength $(0.5 \mathrm{M}$ $\mathrm{NaCl}$ ) to reduce such binding. Therefore, Thiolbinding fractions of $H$. contortus have been shown to be enriched in cysteine protease activity. In the present study, the protein content of thiol-purified antigen was $1.6 \mathrm{mg} / \mathrm{ml}$. This finding is in agreement with the work of Schallig et al., (1997) who observed one major peak and two minor peaks in elution profile. Joshi and Singh (1999) reported two major peaks in elution profile of E/S antigen. Similar protocols for purification of E/S antigen was demonstrated by the other workers. Knox et al., (1999) purified E/S antigen of $H$. contortus using Thiol-sepharose affinity chromatography and observed one major peak in elution profile. Bakker et al., (2004) isolated the fractions of E/S proteins from $H$. contortus by Thiolsepharose affinity chromato-graphy and demonstrated one major peak in bound fraction. The present study clearly demonstrated the use of Thiol-sepharose affinity chromatography for enhancing the purity of E/S antigen.

On western blot analysis, the crude E/S antigen revealed five polypeptide bands against immune serum. Whereas a single band at $66 \mathrm{kDa}$ was detected in thiol-purified antigen. These findings are in accordance with the reports of Knox et al. (2005), Vervelde et al. (2001) and Rathore et al. (2006). In the present trial, sheep were immunized with $500 \mathrm{~g}$ of crude and affinity purified E/S antigen( Aff- $66 \mathrm{kDa}$ ) along with montanide on day 0,30 and 60 intramuscularly. The adjuvant used in the present study produced persistent antibody titres, without causing any tissue reactions at injection site. Several 
investigators conducted immunization trials with different dose schedule in sheep using E/S antigen. Knox et al (1999) immunized lambs on three times at three weeks intervals with $200 \mu \mathrm{g}$ of thiol-purified protein of E/S antigen. Bakker et al (2004) vaccinated sheep with $500 \mu \mathrm{g}$ of thiol - binding fraction of E/S antigen of $H$. contortus. Knox et al (2005) vaccinated lambs three times at three weeks intervals with $500 \mu \mathrm{g}$ of thiol - binding protein of H. contortus.

On ELISA analysis, the serum antibody levels were significantly higher in Group-I than Group -II. The reason for increase in serum antibody levels in Group-I might be due to the effect of administration of thiol-purified antigen which induced strong antibody responses. Similar observations were made by many workers. Schallig et al. (1994) observed significant elevation of serum antibody levels 2 weeks after second immunization in vaccinated sheep. Schallig and Leeuwen (1997) reported a constant increase in serum antibody responses two weeks after first immunization and subsequent immunization boosted the response. Similarly, a strong serum antibody titres were observed in sheep immunized with E/S antigen by Joshi and Singh 1999. Redmond and Knox (2004) observed a significant increase in serum antibody titres in affinity purified protein immunized group. Knox et al. (2005) demonstrated a gradual elevation of serum antibody responses two weeks after first immunization in thiol-purified antigen vaccinated sheep compared to control sheep.

\section{Conclusion}

Based on the results, it was concluded that the thiol-purified E/S antigen induced significantly higher serum antibody levels than crude E/S antigen till $20^{\text {th }}$ week of immunization and thereafter gradual decrease noticed. Further, it indicates that the thiol-purified E/S antigen are highly immunogenic in nature and would be useful for potential protective purpose in ovine haemonchosis.

\section{Acknowledgements}

The authors are grateful to the Tamilnadu Veterinary and animal Sciences University, Chennai for the facilities provided during the course of study.

\section{Conflict of interest} interest.

Authors declare that they have no conflict of

\section{References}

1. Anbu K.A. and Joshi P. (2008). Identification of a $55 \mathrm{kDa}$ Haemonchus contortus excretory/secretory glycoprotein as a neutrophil inhibitory factor. Parasit. Immunol. 30: 23-30.

2. Bakker N., Vervelde L., Kanobana K., Knox D.P and Yatsuda A.P. (2004). Vaccination against the nematode Haemonchus contortus with a thiol -binding fraction from the excretory/secretory products. Vaccine. $22: 618-628$.

3. Gross S.J., Ryan W.G. and Ploeger H.W. (1999). Anthelmintic treatment of dairy cows and its effect on milk production. Vet. Record. $144: 581-587$.

4. Joshi P. and Singh B. P.(1999). Isolation and characterization of two low molecular weight protective antigens of Haemonchus contortus. Indian J. Anim. Sci. 69:284-288.

5. Karanu F. N., Rurangirwa F. R.., McGuire T. C. and Jasmer D. P. (1993). Haemonchus contortus : Identification of proteases with diverse characteristics in adult worm excretory - secretory products. Exp. Parasitol. 77 : 362-371.

6. Knox D.P., Smith S.K. and Smith W.D. (1999). Immunization with an affinity purified protein extract from the adult parasite protects lambs against Haemonchus contortus. Parasit. Immunol. 21 : 201210.

7. Knox D. P., Redmond D. L., Newlands G .F., Skuce P. J. and Smith W D. (2003). The nature and prospects for gut membrane proteins as vaccine candidates for Haemonchus contortus and other ruminant trichostrongyloids. Intl. J. Parasitol. 33 : 1129-1137.

8. Knox D. P., Smith S .K., Redmond D .L. and Smith W. D. (2005). Protection induced by vaccinating sheep with a Thiol-binding extract of Haemonchus contortus membranes is associated with its protease components. Parasit. Immunol. 27 : 121-126.

9. Laemmli U. K. (1970). Cleavage of structural proteins during assembly of the head of Bacteriophage T4. Nature. 227 : 680-685.

10. Meeusen E.N.T., (1996). Rational design of nematode vaccines., Natural antigen. Int. J. Parasitol. $26: 813-818$.

11. Newton S. E. and Munn E. A. (1999). The development of vaccines against gastro intestinal nematode parasites, particularly Haemonchus contortus. Parasitol. Today 15 : 116-122.

12. Rathore D. K., Suchitra S., Saini M., Singh B. P and Joshi P. (2006). Identification of a $66 \mathrm{kDa}$ Haemonchus contortus excretory / secretory antigen that inhibits host monocyts. Vet. Parasitol. $138: 291$ 300 .

13. Redmond D.L. and Knox D.P. (2004). Protection studies in sheep using affinity purified and recombinant cysteine proteinases of adult Haemonchus contortus. Vaccine. 22 : $4252-4261$.

14. Schallig H.D.F.H., Leeuwen M.A.W. and Cornellisen. (1997). Protective immunity induced by vaccinaion with two Haemonchus contortus excretory/ secretory proteins in sheep Parasit. Immunol. 19: 447453. 
15. Schallig H. D. F. H. and Van Leeuwen M.A.W. (1997). Protective immunity to the blood feeding nematode Haemonchus contortus induced by vaccination with parasite low molecular weight antigens. Parasitology. $114: 293-299$.

16. Schallig H. D. F. H., Van Leeuwen M. A. W. and Hendrikx W. M. L. (1994). Immune responses of Texel sheep to excretory / secretory products of adult Haemonchus contortus. Parasitology. 108:351-357.

17. Skuce, P.J., Redmond, D.L., Smith, W.D. and Knox, D.P. (1999). Molecular cloning and characterization of gut derived cysteine proteinases associated with a host protective extract from Haemonchus contortus. Parasitology. 119:405-412.

18. Smith P. K., Krohn R. I., Hermanson G. T., Mallia A V., Gartner F. H., Provenzano M. D., Fujimoto E. K., Goke N. M., Olson B. J. and Klenk D. C. (1985). Measurement of protein using bicinchoninic acid. Anal. Biochem. 150:76-85.

19. Snedecor G. M. and Cochran W. G. (1968). Statistical methods. Oxford and IBH Publications, Calcutta. 1393.

20. Sood M. L. (1981). Haemonchus in India. Parasitology. 83 : 639-650.

21. Soulsby E. J. L. (1982). Helminths, Arthropods and Protozoa of domesticated animals. $7^{\text {th }}$ edn.
Bailliere Tindall. London : 234-235.

22. Suchitra S. and Joshi P. (2005). Characterization of Haemonchus contortus calreticulin suggest its role in feeding and immune erasion by the parasite. Biophy. Biochem. Acta. 1722:293-303.

23. Towbin H., Staehelin T. and Gordon J. (1979) Electrophoretic transfer of proteins from polyacrylamide gels to nitro cellulose sheep : procedure and some application. Proceedings of National Academy of Sciences USA. 76:4530-4534.

24. Vervelde L.,Kooyman F. N .J., VanLeeuwen M.A. W., Schallig H. D. F. H., Cornelissen A. W. C. A (2001). Age-related protective immunity after vaccination with Haemonchus contortus excretory/ secretory proteins. Parasitol. Immunol. 24 : 189-201.

25. Waller, P.J.F., Echevarria, C. and Hansen. (1996). The prevalence of anthelmintic resistance in nematode parasite of sheep in Southern Latin America - General Overview. Vet. Parasitol. 62:181-187.

26. Yatsuda A. P., Krijgsveld J., Cornelissen A. W., Heck A. J. and de Vries E. (2003). Comprehensive analysis of the secreted proteins of the parasite Haemonchus contortus reveals extensive sequence variation and differential immune recognition. J. Biol. Chem. 278 : 16941-16951.

$$
* * * * * * * *
$$

